African Crop Science Journal by African Crop Science Society is licensed under a Creative Commons Attribution 3.0 Uganda License. Based on a work at www.ajol.info/ and www.bioline.org.br/cs DOI: http://dx.doi.org/10.4314/acsj.v24i1.2

\title{
TRACING UGANDA'S GLOBAL PRIMARY ORGANIC PINEAPPLE VALUE CHAIN
}

N. KWIKIRIZA, J. MUGISHA, P. RYE KLEDAL ${ }^{1}$, K. KARANTININIS ${ }^{2}$ and C. NAMUWOOZA ${ }^{3}$ College of Agricultural and Environmental Sciences, Makerere University, P. O. Box 7062, Kampala, Uganda

${ }^{1}$ Institute of Global Food and Farming, IGFT.Dk-RyMarksvej 89, 1tv-2900 Hellerup, Denmark

${ }^{2}$ Swedish University of Agricultural Sciences (SLU), Department of Economics, P.O. Box 7013, SE-750 07, Uppsala, Sweden

${ }^{3}$ National Organic Agricultural Movement of Uganda (NOGAMU), P.O. Box 70071, Kampala, Uganda Corresponding author: normankwikiriza@gmail.com

(Received 20 October, 2015; accepted 22 February, 2016)

\begin{abstract}
The organic sector is one of the fastest growing sectors globally. The sector provides an opportunity for developing countries to export high value products in the global market. One such opportunity for Uganda is the export of organic pineapples. The organic pineapple enterprise is relatively new, having existed for approximately 10 years. This paper traces the organic pineapple value chain, characterises and explains the functions of the actors in the chain. The study used the Global Value Chain Analysis Framework, using data obtained from 140 organic farmers, 10 exporters and 3 support institutions in Uganda. It is clear from the study that the chain is private- sector-driven, has relatively young smallholder farmers, and comprises of 10 small scale export companies. Only $45 \%$ of the organic pineapples produced by farmers reach the organic consumers. Reasons for this included limited processing capacity of exporters, competition from conventional buyers and the few local organic consumers. Other reasons were declining soil fertility, limited regulative institutional support and poor infrastructure. We recommend increased use of soil amendments, favourable legislations and investment environment, increased horizontal coordination among exporters and increasing the range of the organic export products in order to increase organic pineapple sales.
\end{abstract}

Key Words: Certification, organic consumer value stream

\section{RÉSUMÉ}

L'agriculture organique est un secteur en essor rapide dans le monde. Ce secteur offre aux pays en voie de développement d'exporter des produits de grande valeur sur le marché international. Une telle opportunité pour Ouganda est l'exportation de l'ananas organique. Cette chaine de valeur est relativement neuve, car, n'ayant existe que pendant 10 ans. La présente étude retrace la chaine de valeur de l'ananas organique, fais sa caractérisation et explique le rôle des acteurs de la chaine. Cette étude s'est servi du cadre de travail de l'analyse globale des chaines de valeurs, les données utilisées ont été collectées auprès de 140 producteurs de l'ananas organique, 10 exportateurs et 3 institutions d 'appui en Ouganda. L'étude a clairement indique que le secteur est essentiellement prive, avec de petits de producteurs relativement jeunes et 10 petites entreprises d'exportation. De toute la quantité d'ananas organique produite, Seulement $45 \%$ arrivent au niveau des consommateurs locaux. Ceci est dû à la faible capacité de transformation en produits finaux, a la compétition venant des acheteurs non locaux. Autres raisons évoquées sont la baisse de fertilité des sols, le manque d'infrastrure, de lois et d'institution de regulation. Nous recommandons que l'ammendement des sols soit renforcé, que l'environnement des affaires et les législations visent à favoriser le secteur, que la collaboration entre exportateurs soit renforcée afin de promouvoir le secteur d'ananas organique.

Mots Clés: Certification, consommateurs, chaine des valeurs 


\section{INTRODUCTION}

Uganda is one of the developing countries benefitting from the growing global organic market, through export of organic fruits. Uganda has the second largest number of certified farmers in the World, after India; and has the largest area under organic agriculture in Africa (Willer et al., 2014). The national share of organic land to the total arable land in the country is $1.43 \%$. Although the sector is small, its growth is impressive. For instance, the total agricultural land in Uganda under certified organic production increased by $14.7 \%$ between 2005 and 2011; and the value of the organic exports also increased from US \$4.6 million in 2003 to US \$36.9 in 2010 (Namuwoza and Tushemerirwe, 2011). Fruits are the third most exported organic products, in terms of volumes, after coffee and cotton; and organic pineapples make $75 \%$ of the organic fruits exported (Namuwoza and Tushemerirwe, 2011).

The participation of Uganda in the global organic market is important in providing an alternative export strategy, in the face of increasing competition, and the downward spiral in the global market for traditional exports which developing countries heavily depend on (Fitter, 2001; Ponte, 2002). Tracing the organic pineapple value chain helps in identifying critical points for upgrading and positioning in the global market, which is becoming more dynamic because of globalisation (Kaplinsky and Morris, 2001). The organic pineapple export subsector has the capacity to thrive in Uganda because of the fairly fertile soils; the tropical climate and the history of less use of inorganic chemicals (Agro Eco and Grolink, 2008). Willer et al. (2008) indicated that organic agriculture requires less financial input and relies more on the available natural and human resources which can be afforded by the smallholder farmers. However, there is paucity of information related to mapping of organic pineapple value chain in Uganda. The objective of this study, therefore, was to trace the actors in the organic pineapple value chain and examine their activities, with a view of finding out policy intervention areas that can lead to increased sale of organic pineapples to organic consumers.
This study was based on the Global Value Chain Analysis Framework (Kaplinsky and Morris, 2001). The framework emphasizes dynamic interlinkages within the productive sector and the way firms and countries are globally integrated. The scope of analysis includes the flow of economic, organisational and coercive activities between actors; both locally and at a global scale. By expanding the analysis beyond borders, the framework puts value to the participation of developing countries in the global market, and by analysing the organisational and coercive activities, the framework helps in understanding the policy environment in which the chain operates. In this paper, the actors and the activities involved in the chain from conception, up to final actors, were mapped. Attention was also put on the vertical and horizontal links between the actors. The description and analysis of the chain in this paper concentrates on the organic consumer value stream and does not attempt to compare organic and conventional consumer value streams of the organic pineapple value chain.

Data used in the analysis were obtained from both primary and secondary sources. The main primary data were from 140 organic pineapple farmers in Central Uganda in 2013, 10 export companies and 5 organic chain support institutions. Probability proportional to size sampling technique was used to sample farmers (Bar-Hillel, 1979). In this method, the export companies provided a list of farmers with whom they had contracts. The contribution to the sampled 140 farmers depended on the number of farmers the company had contract with. Participatory methods were also used in data collection, and these included 4 Focus Group Discussions (5 -12 farmers), 2 stakeholder meetings and 4 unstructured key informant interviews. Personal observations were made as some activities were done by some farmers ( 6 farmers) on their farms, and exporters (7 exporters) at the export premises. These participatory methods were used to validate results obtained from the structured questionnaires. 
Secondary information was used to describe actors and activities outside Uganda. This was done through literature review of newsletters, bulletins and publications of specialized international organizations that support Organic agriculture; such as IFOAM, EPOPA and FiBL, Switzerland. At farmer level, comparison of characteristics was made between the farmers, basing on the scale of production. One-way anova (Sidak) tests were implemented using the STATA software to compare farmer characteristics.

\section{RESULTS AND DISCUSSION}

Characteristics of organic pineapple farmers. Both male and female farmers were involved in organic pineapple production (Table 1). Organic pineapple enterprise, thus gives an opportunity to women to earn a living, in a country where a study by Peterman et al. (2011) showed that most cash enterprises were managed by men. It contrasts the organic fruit and vegetable farming in India which is dominated by men (Nandi et al., 2015). The finding implies that the value from organic pineapple enterprise can potentially result into economic and social development of both men and women.

Farmers in the organic pineapple production were relatively young (Table 1). Thirty percent were less than 30 years, $59 \%$ between $31-50$ years and only $14 \%$ above 50 years. The higher participation of the young farmers could be because the organic enterprise is relatively new and more innovative; while the less participation of older farmers could be because of its high labour requirements. A number of studies have shown that young farmers significantly adopt organic enterprises more than older farmers (Vanslembrouck et al., 2002; Gailhard and Bojnec, 2015; Nandi et al., 2015). These studies have also consistently shown innovation and profits as the main drivers of organic adoption among young people. Also, they indicated that high labour costs are the key deterrents, for the older people to adopt organic enterprises. Therefore, organic pineapple production is a brand for the younger generation, which can be extended into the future as long as the welfare gains from the enterprise are positive.
The average education level of the organic pineapple farmers was seven years (Table 1). Education levels were lower among farmers with smaller cropped land. Further analysis showed that females had significantly $(\mathrm{P}<0.05)$ lower education than males. The level of education of farmers has implications on the participation in contract making (Simmons et al., 2005). Therefore, lower education levels may limit the expression of farmers in the bargain for favourable contract terms with the exporters, which consequently limits their access to better markets.

Organic pineapples contributed about 55\% of the household incomes (Table 1). All study farmers mentioned organic pineapples to be the most important income source ahead of other crops. Table 1 shows that the proportion of income contribution from organic pineapple enterprise did not significantly vary with scale of production. The high income contribution of organic pineapples to the small scale famers indicates its potential for improving their welfare. This adds to the evidence synthesised by Markandya et al. (2015) from a number of studies in Asia that organic farming is important in meeting the Millennium Development Goal of eradicating extreme poverty and hunger.

Farming households cultivated about two hectares of land; of which $72 \%$ (1.68 ha) was used for crop production (Table 1). Thus, according to The Food and Agricultural Organisation of the United Nations (FAO) definition of the smallholder farmer (FAO, 2010), that classifies smallholder farmers as those with land less than 2 hectares, organic pineapple farmers were smallholder farmers. The average land size on which organic pineapples were managed was 0.57 hectares. Other studies have shown that organic farming is practiced by smallholder farmers on small plots (Setboonsarng, 2008; Kleeman, 2011; Nandi et al., 2015). Focus Group Discussions revealed that small farms are easy to manage, with regard to following organic production principles. The same reasoning was given by the smallholder organic farmers in Ghana (Kleeman, 2011).

This study revealed that only $16 \%$ of the land owned by the farmers was organically certified. Findings from the Focus Group Discussions indicated that farmers limited the land they certified for organic pineapple production 


\begin{tabular}{|c|c|c|c|c|c|}
\hline \multirow[t]{2}{*}{ Characteristic of the farmer } & \multirow[t]{2}{*}{ Total sample $(n=115)$} & \multicolumn{3}{|c|}{ Scale of organic pineapple production } & \multirow[t]{2}{*}{ P-values } \\
\hline & & $\begin{array}{l}\text { Less than } 0.5 \\
\text { hectare }(n=56)\end{array}$ & $\begin{array}{l}\text { Between } 0.5-1 \\
\text { hectare }(n=32)\end{array}$ & $\begin{array}{c}\text { Above } 1 \\
\text { hectare }(n=27)\end{array}$ & \\
\hline Proportion of females (\%) & 46.00 & 50.00 & 21.88 & 40.74 & \\
\hline Proportion of males (\%) & 54.00 & 36.23 & 29.00 & 34.78 & \\
\hline Age of the farmer (years) & $38.54(11.89)$ & $40.14(12.91)$ & $37.09(10.89)$ & $36.93(10.72)$ & 0.373 \\
\hline Education (Average years of schooling) & $6.7(3.19)$ & $5.88^{\mathrm{a}}(3.34)$ & $7.44^{\mathrm{b}}(2.73)$ & $7.52^{b}(3.19)$ & 0.026 \\
\hline Household size & $6.58(3.49)$ & $6.57(3.65)$ & $5.77(3.07)$ & $7.52(3.51)$ & 0.438 \\
\hline Average land size (ha) & $2.34(1.87)$ & $1.64(1.25)$ & $2.24(1.24)$ & $3.63(1.36)$ & \\
\hline Land under crop (ha) & $1.68(1.17)$ & $1.14(0.73)$ & $1.63(.88)$ & $2.83(1.40)$ & \\
\hline Land under certified organic (ha) & $1.08(1.05)$ & $1.85(2.00)$ & $2.20(1.28)$ & $4.98(3.55)$ & \\
\hline Average land sizes under organic pineapple & $0.57(0.34)$ & $0.28(0.13)$ & $0.73(0.10)$ & $1.86(1.24)$ & \\
\hline Household annual income( US\$) & $1,060(800)$ & $908^{a}(764)$ & $1,024^{\mathrm{ab}}(768)$ & $1,408^{b}(848)$ & 0.027 \\
\hline Proportion of income outside farming (\%) & 26.77 & 28.40 & 24.48 & 26.15 & 0.768 \\
\hline Proportion of income from pineapples (\%) & 52.90 & 52.43 & 52.29 & 54.59 & 0.951 \\
\hline Proportion that were organised in a cooperative (\%) & 27.83 & 32.14 & 28.13 & 18.52 & 0.437 \\
\hline
\end{tabular}


because they were not aware of organic markets for other crops. Another possible explanation is that farmers were more interested in the financial benefits than other benefits of organic farming, such as soil health, environmental protection and nutrition. Earlier studies found that high premiums obtained in organic farming are the main driving force for the adoption of organic enterprises (Padel 2001; Lyons and Burch, 2008). This finding implies that other benefits such as its value to environment, soil health should be communicated to the farmers for the sustainability of the farming system. This communication role can be best taken by local support organisations umbrella, since according to Stolze and Lampkin (2009), export companies are more interested in the profits than in promoting other values of organic farming.

Organic pineapple farming had been practiced in Uganda effectively, since 2005 (Table 2). Further analysis showed that $45 \%$ of the farmers had grown organic pineapples for less than 5 years, while $24 \%$ in $6-10$ years, and $31 \%$ between $11-20$ years. With respect to other countries, organic fruit and vegetable production is more recent in India, where the organic enterprises averagely started in 2008 (Nandi et al., 2015); while in Central Germany, organic farming was practiced since 1993 (Gailhard and Bojnec, 2015). Farmers who had more land under organic pineapples managed the enterprises for more years than their counterparts with less land. The explanation for this could be the profits realised which enabled them to increase the level of production under the enterprise, as pointed out during the Focus Group Discussions

Farmers in Uganda grew pineapples even before they converted to organic pineapple production (Table 2). According to Agro Eco and Grolink (2008), conventional pineapple farming was practiced in Uganda before adoption of organic pineapple production, but with minimal use of chemicals. Evidence from a number of studies (Markandya et al., 2015; Setboonsarng, 2008) has shown that less previous use of chemicals was important in attracting smallholder farmers, and in shortening the transition period for qualifying for certification, from 2-3 years to about 1 year. Indeed, the Focus Group Discussion revealed that the history of less use for chemicals

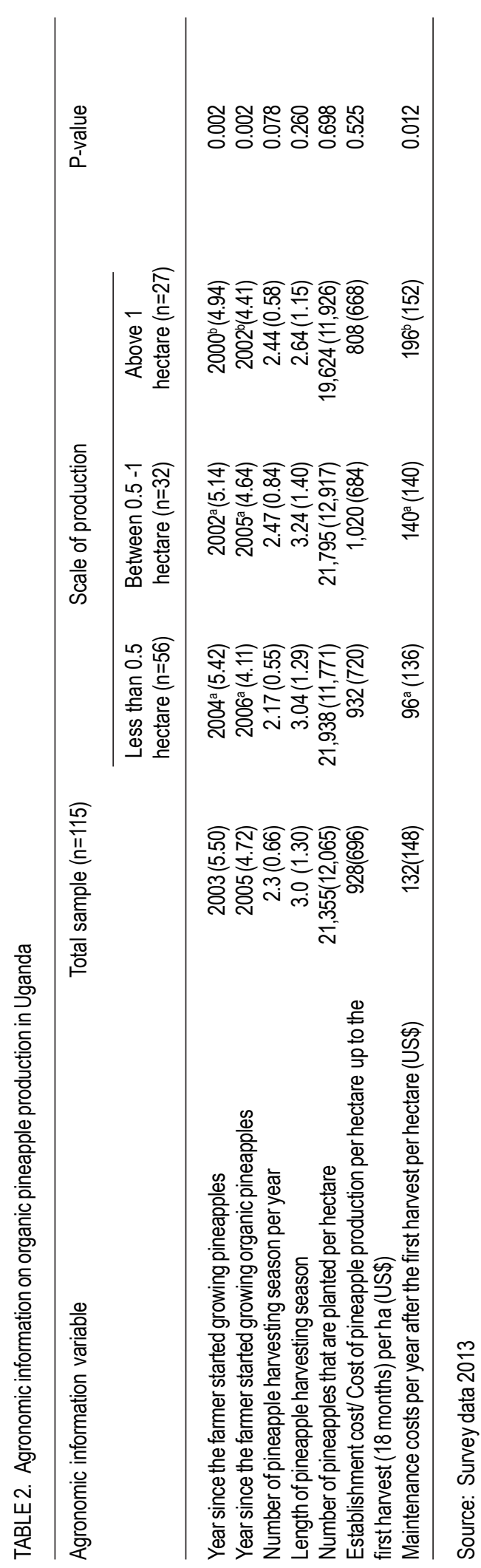


made it simpler for conventional farmers to covert to organic farming.

Smooth Cayene was the main variety grown in Uganda. Only 5\% of the farmers mentioned sweet sugar (Queen Victoria) as another variety grown. According to National Organic Movement NOGAMU (2010), smooth cayenne has a good acid-sugar balance and a uniform barrel shape, which make it ideal for fresh consumption and processing. Queen Victoria was particularly produced for the fresh export market because of its small size $(0.5-1.0 \mathrm{~kg})$. Interviews with exporters revealed that small size pineapples are preferred by organic consumers outside Uganda, because they are suitable for their small household sizes. A new pineapple variety, MD2, has been introduced in the global market by Fresh Del Monte Produce, a company in Costa Rica. It is the main variety exported from Costa Rica, one of the important organic exporters to Europe and America (Kilcher et al., 2011). Whereas MD2 has significantly affected the market for other varieties in the global conventional market, this has not been the case in the organic market (Pay, 2009). Adoption of MD2 variety by smallholder organic farmers in Ghana has also been slow because of high fertilizer requirements and cost of planting materials (Kleemann, 2011).

Stem suckers were the only planting materials used in establishing new organic pineapple plantations. The stem suckers were preferred over crowns, slips and root suckers because of the relatively shorter time they take to establish. According to NOGAMU (2010), stem suckers were encouraged among farmers because of early maturation (18-20 months after planting) and uniform growth. Uniform growth is important in organic pineapple for easy pruning and weeding of the crop. Uniform growth has no implication on harvesting and marketing, since pineapple flowering is uneven. The suckers were obtained from fully established and ageing organic plots. A total of $26 \%$ of the farmers sourced suckers from other organic farmers (Table 3 ).

Coffee husks and livestock manure were the only soil amendments used by the organic pineapple farmers. Coffee husks were used by $30.4 \%$ of the farmers and its use did not vary significantly $(\mathrm{P}<0.01)$ with the scale of production.
Coffee processing plants were the main source of coffee husks (Table 3), and farmers, in addition to paying for the materials, incurred more costs to transport to their farms.

Livestock (cattle manure) manure was used by $16 \%$ of the farmers, and the main source was farmer's own livestock. With the non-use of chemical fertilisers, coffee husks and livestock manure become important soil amendments. Findings from the Focus Group Discussions indicated that farmers who used coffee husks had their plantation's life extended by up to six years compared to four years for non-users. Coffee husks users, after a short fallow of about two years, planted another pineapple crop in the same plot, which was not the case with the non-users. Use of coffee husks was also reported by farmers and exporters to contribute to the consumer product attributes of sweetness, juiciness and prolonged shelf life.

Apart from planting materials, coffee husks and livestock manure, other inputs which were used by farmers are presented in Table 3. The common equipment used (hoes and machetes) were bought from the local village traders and were accessible and affordable. Whereas wheelbarrows and gumboots were available in the village shops, their use was very low (Table 3 ) due to their high cost. At the time of study, gumboots and wheelbarrows cost US\$ 6 and US\$ 50 respectively. Gumboots were necessary for providing protection against the sharp serrated pineapple leaves during weeding. Wheelbarrows helped in distribution of manure or coffee husks in the field.

Farmers planted about 21,355 pineapples per hectare (Table 2). This was significantly lower $(\mathrm{P}<0.01)$ than the recommended plant population 54,450 per hectare by NOGAMU (2012). This planting density was not significantly different from that of organic pineapples in Ghana, estimated to be 20,000 per hectare (Kleemann, 2011). High plant densities are particularly important in the flesh organic pineapple export market because of the advantage of producing small sized pineapples, which are preferred in this market. This finding implies that, government, exporters and NGO extension agents need to promote high plant densities in the organic pineapple plots. 
TABLE 3. Input use by organic pineapple farmers and source of inputs used in Uganda

\begin{tabular}{|c|c|c|c|}
\hline \multirow{2}{*}{$\begin{array}{l}\text { Input use } \\
\text { Type of input }\end{array}$} & \multicolumn{3}{|c|}{ Input use detail } \\
\hline & Proportion (\%) & Source of input & $\begin{array}{l}\text { Proportion that got the input } \\
\text { from the source mentioned }\end{array}$ \\
\hline \multirow[t]{2}{*}{ Planting materials } & 100 & Fellow farmers & 74.2 \\
\hline & & Own source & 25.8 \\
\hline \multirow[t]{6}{*}{ Coffee husks } & 30.4 & & \\
\hline & & Local/Village traders & 2.3 \\
\hline & & Town traders & 12.9 \\
\hline & & Traders in the city & 3.2 \\
\hline & & Fellow farmers & 9.7 \\
\hline & & Coffee factories & 71.0 \\
\hline \multirow[t]{4}{*}{ Livestock manure } & 15.7 & & \\
\hline & & Own livestock & 77.8 \\
\hline & & Local village traders & 11.1 \\
\hline & & Other sources & 11 \\
\hline \multicolumn{4}{|l|}{ Equipment } \\
\hline Hoes & 100 & Local village traders & 73 \\
\hline Machetes/knives & 76.5 & Town traders & 11.5 \\
\hline Wheel barrows & 20 & City & 2 \\
\hline Gumboots & 10.4 & Export companies & 5 \\
\hline Axes & 12.2 & Fellow farmers & 1 \\
\hline
\end{tabular}

Source: Survey data 2013

Farmers spent about US\$ 928 per hectare to establish pineapple plots up to the first harvest (18 months). The maintenance costs averaged US\$ 132 (Table 2). The maintenance costs increased progressively, with the scale of production. Weeding was the most time consuming and expensive activity (Fig. 1). Weeding was difficult because of the sharp serrated pineapple leaves and the rhizomatous weeds, especially Digitaria scalarum.

All farmers harvested pineapples immediately after part of the fruit changed from green to yellow. A total of $60 \%$ of the farmers used a sharp knife to cut off the fruits, and $13 \%$ of the farmers brushed the fruits before sale to the exporters. These practices were done to meet the requirements of the exporters. The Focus Group Discussions indicated that timely harvesting extended the shelf life, at least for two days, and minimised bruising, during transportation. Timely harvesting is particularly important for pineapples, because they do not ripen after harvest. Overripe fruits rot very fast and are susceptible to bruises during harvesting and transportation. Also, overripe fruits are deficient in flavour (NOGAMU, 2010). Fruit yields were about 20 tonnes per hectare. This yield compares well with the yields in Ghana (Kleemann, 2011), which is one of the World's leading fresh organic pineapple exporting country.

Organic pineapples were intercropped with at least 3 other crops (Table 2). Common intercrops, in order of importance were beans, banana, coffee, paw paws, mangoes and avocadoes. Intercropping was intended to utilise the small land owned more effectively and also to exploit the organic market for the fruit trees exported to international markets, alongside pineapples. Intercropping is encouraged in organic production systems, because it reduces overhead costs for the export companies, since certification costs are spread over several crops (van Elzakker and Eyhorn, 2010). NOGAMU (2012) recommended intercropping of pineapples with 
banana and other fruit trees to provide shade to prevent sun-burning of pineapples

Farmers' participation. Organic pineapples sold by the farmers followed two value chain streams; (i) the organic consumer value stream, and (ii) the conventional consumer value stream (Table 4). A total of $45 \%$ of the organic pineapples followed the organic consumer value stream compared to $55 \%$ that followed the conventional consumer value stream. Only $7 \%$ of the farmers sold all of their organic pineapples to the organic buyers. This was attributed to the low capacity of the organic buyers, the phenology of the crop, the demand by the local organic consumers, and the risk behaviour of the smallholder farmers.

All interviewed organic exporters/buyers lacked capacity to handle the farmers produce, especially in the peak periods. The driers owned by the exporters were of limited capacity to handle the pineapples produced. Exporters mentioned lack of adequate financial resources and high

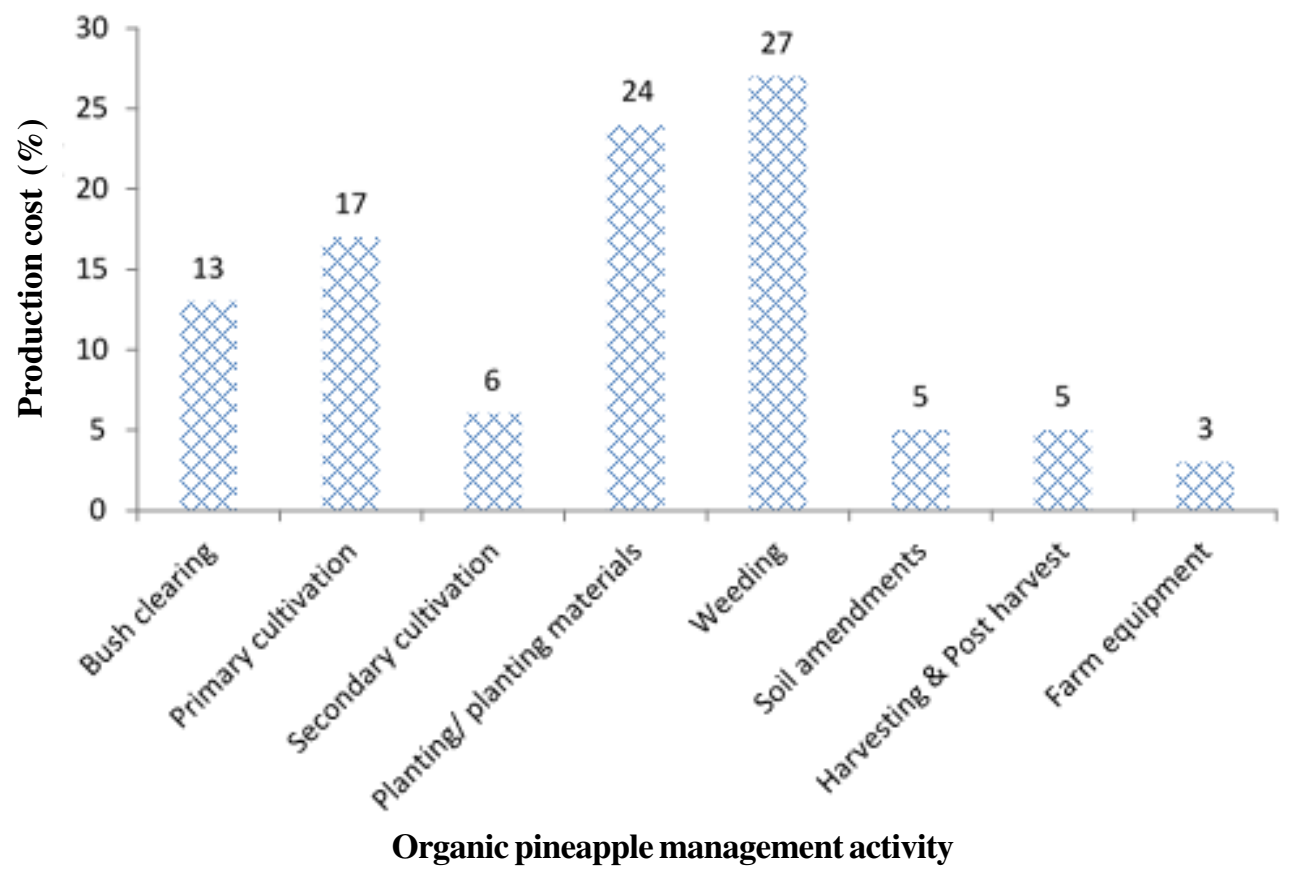

Figure 1. Percentage expenditure of farmers on the different agronomic inputs in organic pineapple production in Uganda.

TABLE 4. Sale of organic pineapples at farm level in Uganda

Consumer value stream Proportions (percentages)

Sale to organic pineapple consumers

Proportion of pineapples sold to local consumers 1

Proportion of pineapples Exported to consumers outside Uganda

Sale to conventional pineapple consumers

$\begin{array}{lr}\text { Proportion sold to final consumers within the farm communities } & 10\end{array}$

Proportion sold to local retailers within the farm communities 6

$\begin{array}{lr}\text { Proportion sold to wholesalers who later sale to urban consumers } & 16.5\end{array}$

Proportion sold to wholesalers who export to both regional and international markets 16.5

$\begin{array}{lr}\text { Proportion sold to processing industries within Uganda } & 6\end{array}$ 
interest rates, which limited their capacity to procure better quality and high capacity driers. The lending interest rate percentage in Uganda averaged to $21.6 \%$ in 2014 , one of the highest globally (World Bank, 2015). According to Nampewo (2012), the following policies; raising deposit rates, opening new commercial banks, expanding existing commercial branches can help reduce the interest rates. Another option is for organic pineapple stakeholders to advocate for the government support to the Credit Reference Bureau (CRB) so that the problem of loan defaulters, which escalates interest rates, is managed. NOGAMU in collaboration with the Government can lobby International agencies that provide interest free and commercial loans to support the organic sector. Findings show that EPOPA, an international donor agency, promoted the organic sector in Uganda by providing commercial loans and interest free loans (Malins and Nelson, 1999)

The phenology of the organic pineapple plant and its influence on pineapple markets is presented in Figure 2. Newly established crops produced big sized pineapples (averagely $2.5 \mathrm{~kg}$ each), bigger than the average size of $1.5 \mathrm{~kg}$ preferred by the flesh exporters. The large proportion of the big sized pineapples found market with the conventional buyers. However, as the plantation aged (36 - 72 months), fewer and smaller sized pineapples (between $1-1.8 \mathrm{~kg}$ ) were produced, thus becoming suitable for the organic export market. As the plantation continued to age, more pineapples were sold to the organic buyers. The ability to sale at premium prices of the small sized pineapples, from the aged out plantations, was given as one of the motivating factors of producing organic pineapples. This finding supports the use of soil amendments such as livestock manure and coffee husks, which extend the crop life, so that farmers continue to harvest the small size pineapples required in the flesh export market as the plantation ages out.

Based on Table 4, the local sales of organic pineapples were very low (1\%), implying very minimal local organic consumption. This meant that apart from the organic export market, the rest of the organic pineapples were sold to the conventional buyers.

Findings from the study also revealed that the sale of organic pineapples to the conventional buyers was a form of risk management strategy. This study established that $59 \%$ of the farmers preferred to sell to the organic buyers; and the rest to the conventional buyers. The preference

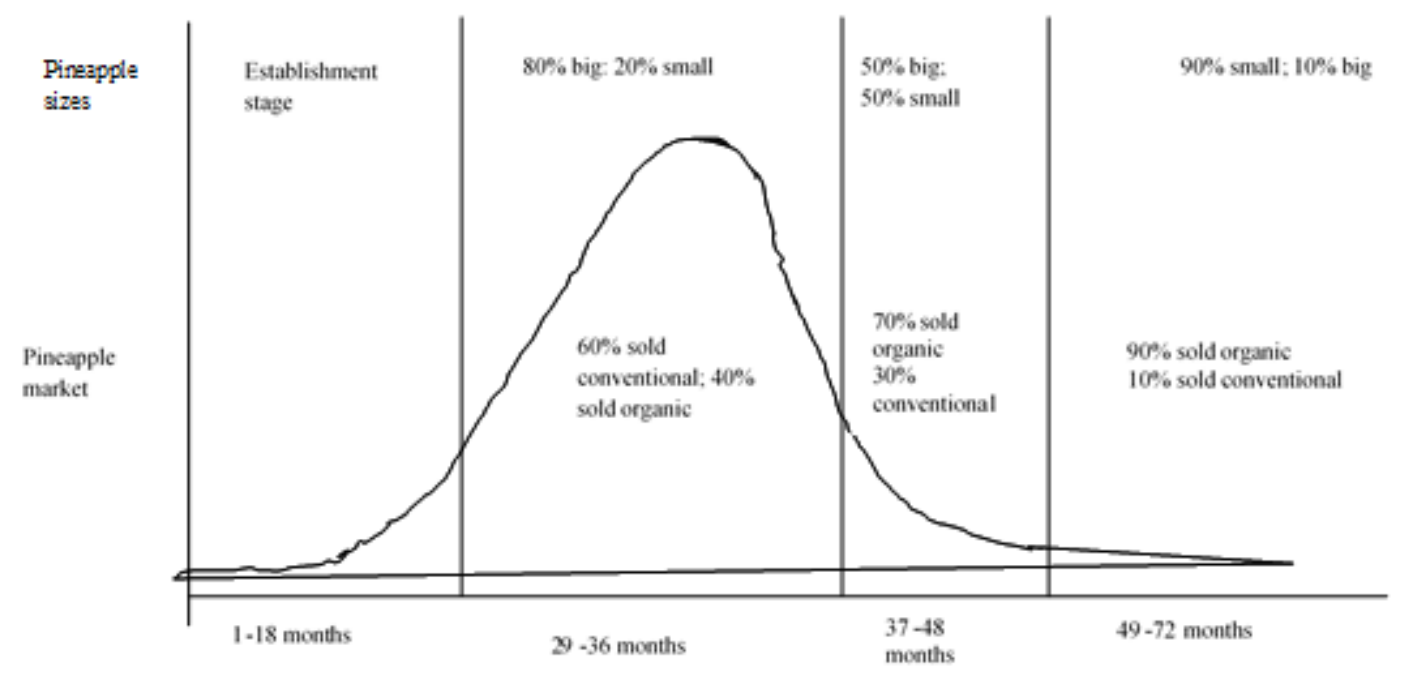

Stage of development of the pineapple crop

Figure 2. Relation between organic pineapple phenology, size of the pineapple and pineapple market in Uganda. 
to the organic buyers was mainly due to the higher premium prices (over $80 \%$ of the responses). An organic pineapple fruit in the peak period was averagely bought at US\$ 0.4 by the organic exporters, compared to US\$ 0.3 by the conventional buyers. Other studies (Padel, 2001; Lyons et al., 2008; Ullah et al., 2015) found premium prices as the main reason which attracts smallholder farmers to organic enterprises.

In part, organic farmers sold to the conventional buyers because of market reliability and convenience of sale, namely fewer restrictions on quality and less rigidity on the frequency and period of sale. Sale to both organic and conventional buyers by smallholder farmers was also observed in Ghana (Kleemann, 2011), with about $44 \%$ sold to conventional buyers. This finding implies that support to the organic sector indirectly benefits the conventional consumer value stream of the organic pineapples.

The second finding in the organic consumer value stream (Table 4) was that there were fewer actors compared to the conventional consumer value stream. There were no retailers or middle men in the organic pineapple exchanges, between farmers and exporters. The exporter procured the organic pineapples in the following ways; (i) through farmer's focal persons (5 export companies); (ii) from individual smallholder farmers (2 exportcompanies); (iii) farmers took the pineapples to the exporter premises (1 export company); and (iv) farmers through their cooperative dried the pineapples before directly selling to the exporters (2 export companies). Fewer intermediaries were common in organic value chains, compared with conventional value chains (Kleeman, 2011).

The direct procurement from farmers was done to ensure that individual farmer's details were recorded, and thus ensure traceability of the product from the final consumer to the producer. According to van Elzakker and Eyhorn (2010), traceability becomes very costly if there are many actors along the chain. It is therefore important for the organic pineapple value chains to keep fewer intermediaries. This can be achieved through establishing strong and detailed contracts between farmers and the export companies. According to Kleemann, (2011) fewer intermediaries lead to strong contracts and easy enforcement.

The organic pineapples, in the conventional value stream, were mostly purchased by the regional and local wholesalers (Table 4). According to the Focus Group Discussions, the local wholesalers distributed organic pineapples mainly to Kampala city markets; while the regional exporters traded the pineapples to two main markets, Juba (South Sudan) and Nairobi (Kenya). The local processing industry absorbed $6 \%$ of the pineapples, an indicator of less consumption of processed pineapples in Uganda.

Organic pineapple exporters. There were 10 organic pineapple export companies in Uganda at the time of this study. Eighty percent of these companies were local. The companies operated within $80 \mathrm{Km}$ from Entebbe International Airport, for proximity to the port of exit. Table 5 shows two main organic pineapple exports, that is, the fresh and the dried organic pineapples. Exporters procured fresh pineapples for either direct export ( 2 export companies) or for processing before export (4 export companies) or both (4 export companies). Pineapples were exported with other fruits like sweet bananas, mangoes and jack fruits.

A study by Danielou and Ravry (2005) showed that development of the organic pineapple sector in Ghana led to the increased export of other fruits. Production and sale of a number of organic products is encouraged in organic value chains because it diversifies incomes for the actors involved. It also reduces overhead costs for the export companies, since certification costs are spread over several crops (van Elzakker and Eyhorn, 2010). The opportunities to market a range of organic fruits and other organic crops, including cereals, pulses, spices and vegetables by the farmers should be explored, by NOGAMU and the Uganda Export Promotion Board, so that they benefit from the premium prices on the crops produced from their organic farms.

The export companies had 5-50 employees. Thus, according to European Commission (2005) classification, they were small enterprises since they employed less than 50 permanent employees. The employment structure had $40 \%$ 
Tracing Uganda's global primary organic pineapple value chain

of females in managerial positions, $15 \%$ in the skilled technical role positions, while a big percentage of females $(60 \%)$ provided unskilled labour. This conforms to the findings in Asia by Markandya et al. (2015) that organic production systems brings about more employment to women, more especially in less technical skills.

Our study found weak horizontal links between export companies in terms of information sharing. Further, no export company outsourced from other organic farmers, apart from those that subscribed to it. Figure 3 shows that no farmer sold to more than one organic export company. The weak horizontal links are partly explained by the certification regime the exporter subscribes to, which prohibited sourcing the pineapples certified by another certification regime. These weak linkages are characteristic of export driven organic value chains, where the role of government and non-government organisations are minimal (Bakewell-Stone et al., 2007).

Horizontal links and cooperation are important in bringing about chain upgrading in organic value chains (Trienekens, 2011). Lazzarini et al. (2008) found that horizontal links among exporters offset the lack of strong regulatory institutions. Furthermore, horizontal linkages established through intercompany relations and joint investments, decrease delivery uncertainty; while increasing quality, consistency in delivery and market power, which facilitate a smooth flow of products and information (Trienekens, 2011). Strong links between exporters in Argetina were effective in influencing government policies to support of organic agriculture (Crucefix, 1998). In absence of Government support, strong links can be promoted by NGOs involved in organic promotion, through stakeholder platforms, where different export companies under different certification regimes are brought together. In this way, market and policy related issues important for the sub-sector are discussed.

The exporters were exclusively involved in selecting, training and meeting the farmer certification costs. They determined when to buy, how much to buy and when to pay the farmers. The cost of certification ranged between US\$ $4,000-12,000$, and companies incurred costs in hiring quality and internal control system management so that organic production principles 


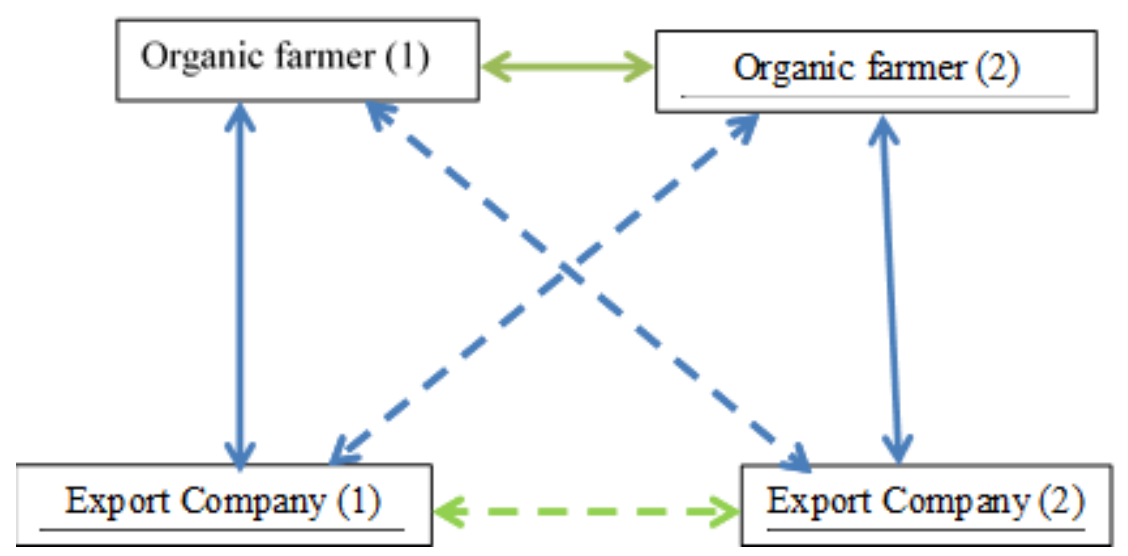

Note: Bold lines signify linkages among actors while dotted lines signify no linkage between actors

Figure 3. Nature of linkages between export companies and farmers in Uganda.

were adhered to. Our study did not find farmers who paid for certification costs individually. This shows that the certification process largely relies on the exporter initiative and efforts. All export companies mentioned certification and monitoring costs as some of the most important challenge they faced. Studies in organic value chains have shown that donor support is crucial for the startup and sustaining high value chains that require certification (Lenne et al., 2005; Stolze and Lampkin, 2009). In some countries, for example, Denmark, the government supports the sector by subsidising certification costs (Daugbjerg et al., 2011). According to Stolze and Lampkin (2009), lack of government support may stifle the organic sector due to imperfect competition, since the sector is young.

All export companies carried out primary transformation activities. Companies that exported fresh pineapples brushed, graded and packaged them in crates. In order to minimise perishability, fruits were transported to the airport for export, immediately after harvest, using specialised company vans.

Companies that exported dry pineapples used either hydro-electricity ( 2 export companies), a combination of solar and hydro-electricity (4 export companies), or a combination of fuel wood and hydro-electricity (1 export company) for drying. Two companies built the capacity of farmers to use simple and cheaper timber-framed 'cabinet' solar driers, also referred to as the Improved Kawanda solar driers (Brett et al., 1996). In this arrangement, farmers organised in groups, delivered their fresh pineapples to a central station, where few farmers were hired to slice and dry the pineapples on behalf of the whole group. Sliced pineapples were spread outside on the trays to utilise the sun rays to dry sliced fresh pineapples. Through this activity, large volumes of dry pineapples were obtained by the exporters from the farmers, without incurring high costs of setting up driers. The main disadvantage of solar driers, as mentioned by the export companies, was compromise on quality, leading to as high as $20 \%$ of rejects, compared to other forms of drying where exporters reported less than 5\% losses. This, therefore, requires research into designing more efficient solar driers that can be used by the smallholder farmers.

Key informants from exporters that dried the fruits revealed that final packaging of dry pineapples products was done in the importing countries. Only one export Company exported fully packaged products. Reasons for doing final packaging outside the country included the unavailability and high cost of packaging materials in Uganda, and the nature of the industry which encourages final packaging in the importing countries. Primary packaging involved use of hard barrier polythene bags in which dry 
pineapple slices, weighing between $5-20 \mathrm{~kg}$ were sealed and exported. Final packaging in the importing countries is in line with Elzakker and Eyhorn (2010) and Trienekens, (2011) who found that importers preferred to do final packaging to meet the needs of their customers, and to comply with private label policies that are country specific. Since the consumers and importers have a strong influence on the actors downstream (Bakewell-Stone et al., 2006), final packaging will likely continue to be done in the importing countries.

Organic pineapples were most exported to Europe (80\%), especially to Belgium, Switzerland, Netherlands, Denmark and Germany. The rest were exported to Asia and the United States of America (USA). This supports the observation by Pay (2009) that Europe is the largest consumer of organic pineapples. From the exporters, the organic pineapples were received by the distributors/importers. Importers transacted directly with exporters in order to reduce the number of actors through which traceability checks would be required. Exporters and importers made contacts during international organic fares. Importers received pineapples from the exporters under the free- on- board (FOB) arrangement. This arrangement is recommended in organic exchanges because of the many and changing organic import requirements in the importing countries (Gibbon and Bolwing, 2007; Kilcher et al., 2011), which create additional transaction costs, especially in terms of information to the exporters.

From the importers, the pineapples are either distributed to the organic specialty shops or supermarkets (Kleeman, 2011). According to Pay (2009), the main challenges faced by the importers were the seasonality in supply and limited range of fruits exported. The small quantities exported are a result of seasonality of the fruits, and inadequate distribution networks (Kilcher, 2011). Other challenges faced by fruit importers in European countries are inadequate distribution networks, requirements for whole farm organic management, which makes the value chain expensive (Kilcher, 2011). These challenges show the need to develop the country organic pineapple sub-sector to achieve reliability in supply.
All exporters revealed that they received more orders than they could meet. This agrees with literature on pineapple exports in Europe (van Elzakker and Eyhorn, 2010; Kilcher, 2011). Studies in the importing countries in Europe indicate that the price premiums for organic pineapples were $50 \%$ higher than other tropical exports (Kilcher, 2011), and the market for pineapple juice and pulp was particularly high, with an annual growth of about 30\% (Kilcher, 2011). This shows positive prospects for the organic pineapple market, which smallholder farmers in Uganda can exploit. There is also need for the export companies to diversify organic pineapple products exported. This can be achieved through training of the export company staff and farmers the various value addition activities by development organizations, NOGAMU and the Government of Uganda.

Chain supporters. The important chain supporters in the organic pineapple value chain included the certification bodies, NOGAMU, Non-Governmental organisations (NGOs) and the Government. These played a role in facilitating the exchange of organic pineapples among all the actors in the chain.

The certification process involved four internationally accredited certification bodies which certified actors along the chain. These were Institute for Marketecology (IMO), Soil association, Ceres, and Uganda Organic Certification Limited (Ugocert) (Table 5). IMO was the most common because its standards covered a bigger geographical scope and was applicable to various private standards, including fair trade. Other certification companies were the East African Organic Products Standards (EAOPS) and the Uganda Certification Company (Ugocert). Ugandan Certification Company is an affiliate of NOGAMU and was developed into a local certifying body in 2004, and later was internationally accredited as a certifying agency in 2009. Interviews with the Ugocert executives showed that Ugocert had reduced certification costs by about $20-30 \%$, by certifying and inspecting farmers on behalf of the international certification bodies. It also certifies farmers under the participatory Guarantee System, which has enabled sale of organic pineapples to the local organic consumers. 
According to Regulation, EC (889/2008) certification is a core activity for all actors along the organic value chains. Like other niche products, certification by a third party is a key requirement in the organic trade (Grunert et al., 2005; Tumushabe et al., 2007). Certification is important because it is through certification that intrinsic and extrinsic qualities of the organic products are audited by tracing all the actors that the product goes through. Through certification, buyers confirm the products for the required attributes, and the premium price charged is justified (Grunert et al., 2005).

The National Organic Movement Uganda was the most important business matching umbrella organisation. NOGAMU was formed in 2005 , and was initiated by the few organic exporters who were then operating in the country under the coordination efforts of the project "Export Promotion of Organic Products from Africa-EPOPA". In addition to its involvement in the creation of NOGAMU, EPOPA organised and trained small producer farmer groups, before linking them to exporters (Agro Eco and Grolink, 2008). When EPOPA phased out in 2008, NOGAMU was well established to take a number of coordination roles. At the time of study, NOGAMU coordinated all the actors through research, training and dissemination of findings. The organisation was also responsible for mobilising for agricultural financing, engaging Government and other stakeholders for institutional support and exploring market opportunities, especially through organising participation of actors in international trade fares.

Apart from NOGAMU, there was less participation of other NGOs and international/ donor organisations in the sector; only $23 \%$ of farmers received support from NGOs. Among the NGOs was the Uganda Cooperative Alliance (UCA). UCA organised organic farmers into organic producer groups, through which they received financial support in procuring driers, received trainings and facilitated access to credit.

The role of NGOs in promoting the organic value chains has been evaluated in a number of studies (Perez-Aleman and Sandilands, 2008; Trienekens, 2011). In such studies, NGOs were credited for the formation of strong lobby platforms to reduce commercial interest rates, advocate for access to electricity and in lowering power tariffs.

Since the formation of NOGAMU, the organic sub-sector has been mainly private-sector-driven, and at the time of study, there was no organic policy in place. A number of studies have highlighted the importance of government and NGOs in the organic value chains (McDermott, 2007; Trienekens, 2011). Through public expenditure, the government can perform marketing and communication campaigns to encourage organic consumption, support the certification process and promote other values of organic agriculture (Sirieix et al., 2011). Murphy (2007) found that insufficient government support limited the upgrading of furniture industry in Mwanza, Tanzania.

\section{Constraints in the organic pineapple value chain.}

There were several constraints within and without the organic pineapple value chain. The major ones included:

Low soil fertility. At farmer level, there was less use of natural soil amendments, i.e coffee husks and livestock manure (Table 3). The main reason for the less use of manure was less livestock management among the organic pineapple farming households; yet for coffee husks, the cost was prohibitive to most farmers. At the time of the study, the average price for one tonne of coffee husks was US\$ 40, and farmers required an average of 25 tonnes per hectare. The less use of soil amendments led to declining soil fertility, as mentioned by $34 \%$ of the farmers. Decline in soil fertility was associated with a shorter life span of the pineapple crop, not exceeding four years after establishment. Because of the declining soil fertility, farmers shifted to new and distant but fairly virgin areas, which made monitoring and traceability by the exporters difficult.

Field establishment costs. The organic pineapple management was mostly costly at establishment stage of the plantations. Establishment costs were seven times higher than maintenance costs (Table 2). From the Focus Group Discussions, farmers mentioned bush clearing, primary cultivation, seed bed preparation and weeding as the most labour consuming and capital intensive activities. 
Tracing Uganda's global primary organic pineapple value chain

TABLE 6. Constraints farmers face in the marketing of organic pineapples in Uganda, expressed in percentages

\begin{tabular}{lcccc}
\hline Challenge & Total sample $(\mathrm{n}=115)$ & \multicolumn{3}{c}{ Scale of organic production } \\
\cline { 3 - 5 } & & $\begin{array}{l}\text { Less than } 0.5 \\
\text { hectare }(\mathrm{n}=56)\end{array}$ & $\begin{array}{c}\text { Between 0.5-1 } \\
\text { hectare }(\mathrm{n}=32)\end{array}$ & $\begin{array}{c}\text { Above 1 } \\
\text { hectare }(\mathrm{n}=27)\end{array}$ \\
\hline Low prices & 55 & 48 & 55 & 66 \\
Price fluctuations & 17 & 17 & 21 & 15 \\
Exploitation by buyers & 18 & 15 & 22 & 8 \\
Seasonal buyers & 12 & 9 & 13 & 20 \\
Purchase of less volumes & 7 & 9 & 5 & 7 \\
Other challenges & 5 & 6 & 6 & 0 \\
\hline
\end{tabular}

These activities necessitated hiring of labour. Because of high establishment costs, the Focus Group Discussions mentioned that they opted to manage small plots.

Pests and diseases. About $17 \%$ of the farmers mentioned pests and diseases as important constraints. The pests mentioned were termites, mealybugs and the mealybug tending ants. Termites were mentioned as the most dangerous pests because of their potential to destroy the whole plantation. The common disease mentioned was pineapple wilting, which farmers associated with ants and poor soil fertility. Farmers mentioned the consequences of pests and diseases as poor yields and poor quality fruits, which were consequently rejected by the exporters. From the interviews with the exporters, pest and disease infestations of the fruits were mentioned as the most important quality aspect that led to reject by buyers. Therefore, exporters paid attention to buying pest and disease free fruits. At the time of the study, there were no effective recommended organic control measures against these pests. There, is therefore, need to promote the natural remedies such as use of pawapaws, tephrosia, Black jack and neem to control mealybugs (NOGAMU, 2010) to the smallholder farmers. Relevant institutions should engage in further research to find other ways of managing the pest, disease and soil fertility problems.

Marketing constraints. The marketing constraints included low prices, as mentioned by over $55 \%$ of the farmers. This implies that, although the export companies paid premium prices above the conventional prices, farmers preferred higher prices basing on the costs incurred in following organic principles. Other constraints which were mentioned were exploitation by buyers, fluctuation of prices, seasonality of the buyers and purchase of fewer volumes than what farmers produced. These constraints arose mainly because of the seasonality nature of the organic pineapples. During the peak season (May - June and November - January), export companies bought less a fraction of farmers produce because of their limited processing capacity. Some contact (liaison) farmers also took the advantage to sell more of their own farm produce and less of the other farmers who subscribed to the same company. Further, the conventional market, which was important in procuring excess pineapples beyond what the exporters could buy, got saturated in the peak season, thus posing a challenge for the small holder farmers in finding market. Prioritising the fruit sector by the government can help in addressing the constraint. This is because private investors will be encouraged to set up local processing industries which can buy excess pineapples that are not bought by organic exporters especially in the peak periods. The promotion of processing industries was mentioned as one of the reasons that led to the growth of the pineapple industry in Ghana (Danielou and Ravry, 2005).

The main challenges at the export level were the lack of processing capacity, seasonality of supply, high certification costs and consumer requirements of small sized pineapples, especially 
in the flesh export market. All exporters mentioned constraints related to infrastructure. High electricity costs, unreliable and inadequate electricity supply were the most important infrastructure challenge. Unreliable and inadequate electricity led to losses arising from no production and poor quality processed products that could not be exported. According to Electricity Regulation Authority, average commercial prices for electricity were $0.15 \mathrm{US} \$$ / Kwh (ERA, 2016), and is one of the highest in the East African region. The country relied on thermal and hydroelectricity, with generation per capita of $4.7 \%$, which is below the customer growth (Mawejje, 2012). The constraints on electricity require the promotion of alternative energy sources such as wind, solar PV and biogas; especially by the Government. Another option for export companies is to invest in utilising the pineapple waste generated during processing, to produce biogas as an alternative energy source.

Poor road network was mentioned to be important in affecting the quality of pineapples, as humps caused bruises on the fruits. Poor road networks affected the procurement of pineapples from farmers. With poor road networks, exporters incurred high transportation costs to perform routine quality checks, training of the farmers and in the procurement of the pineapples. According to Reinikka and Svensson, (1999), poor infrastructure significantly hinders private investment. Reinikka and Svensson further asserted that improvement in public sector performance is a precursor for the private sector to thrive. Infrastructure development was mentioned as one of the critical success factor that led to the growth of Ghana's pineapples export industry (Danielou and Ravry, 2005).

The importers faced the challenges of unreliable supplies from exporters, as none of the exporters met the importers' quantity demands. Importers were constrained by the changes in the customer requirements, due to the dynamic nature of the organic sector. For example, export of organic products by air is regarded by some section of organic consumers as non-compliant with organic production principles (Gibbon and Bolwing, 2007). The sector also demands a long list of documentation and procedures which increase transaction costs (Kilcher et al., 2011).
These challenges of less supply from exporters can be addressed by participation of the government and donors especially in providing subsidies for certification and inspection, tax holidays for organic investors, creation of incentives for local and foreign investors. These policy measures have been used in China (Kallander and Rundgren, 2008) and in Tunisia (Adebiyi, 2014) to solve the supply problems and thus improving the organic sector in these countries.

Support institutions. There was less participation of the support institutions, especially government and NGOs, and this limited the growth of the sector. The sector is considerably young and the contribution of the NGOs in supporting the actors, especially in market search, training and organising farmer groups was mentioned by stakeholders as paramount. The increase in participation of NGOs and professional organisations can be enhanced by NOGAMU, especially through steering the stakeholder platforms.

Organic policy. There is lack of an effective organic policy in Uganda. This has impeded the growth of the organic sub-sector and organic pineapples in particular. At the time of the study, there was a threat of passing of legislations, such as legalising the production and consumption of Genetically Modified Organisms (GMOs) in the country that would potentially affect the performance of the organic sector. Having a policy in place implies that the Government sets goals and objectives that direct the sub-sector, makes organic policies that inform other agricultural policies to avoid antagonism, and also helps in multilateral trade negotiations, which are key in the marketing of organic products (Walaga et al., 2005). According to McDermott (2007), Murphy (2007) and van Elzakker and Eyhorn (2010), where organic policies are in place, exporters have been supported, especially in cost sharing the payment of certification costs and passing favorable legislation for the organic sector. Conversely, where organic policies have been weak, there have been limited upgrading in the organic chains. With an organic policy in place, the Government can establish a special desk 
in the Ministry of Agriculture Animal Industries and Fisheries, for purposes of attracting investors, mobilising for donor support and bringing the stakeholders together.

\section{ACKNOWLEDGEMENT}

The International Centre for Research in Organic Food Systems (ICROFS) supported the projectProductivity and Growth of Organic Value Chains (ProGroV) which in turn funded this study.

\section{REFERENCES}

Adebiyi, J.A. 2014. Organic agriculture development strategies in Tunisia and Uganda: Lessons for African organics. https:/ /scholar.google.com/scholar?q =Adebiyi\%2C+J.A.\%2 C+2014.+Organic + agriculture+develop ment+strategies+ in+Tunisia+and+Uganda\%3 A+Lessons + for + African+organics.\& btnG $=\& h \mathrm{hl}=\mathrm{en}$ \&as sdt=0\%2C5. Accessed on 03.04.2015

Agro Eco, B.V. and Grolink, A.B. 2008. Organic exports: A way to a better life? http:// www.grolink.se/epopa/Publications/Epopaendbook.pdf. Accessed on 28.09.2015.

Bakewell-Stone, P. 2006. Sustaining livelihoods through organic agriculture in Tanzania: A sign-post for the future. Masters thesis at Norwegian University of life Sciences, Department of plant and environmental sciences. P.36ff

Bar-Hillel, M. 1979. The role of sample size in sample evaluation. Organizational Behavior and Human Performance 24(2): 245-257.

Brett, A., Cox, D.R., Trim, D.S., Simmons, R. and Anstee, G. 1996. Producing solar dried fruit and vegetables for micro- and small-scale rural enterprise development, Handbook 4. Business Profitability. Natural Resources Institute, Chatham, UK. 30pp.

Crucefix, D. 1998. Organic agriculture and sustainable rural livelihoods in developing countries. Report by Natural Resources and Ethical Trade Programme, June. https:// scholar.google.com/scholar? $\mathrm{q}=$ Crucefix $\% 2 \mathrm{C}+\mathrm{D} . \% 2 \mathrm{2}+1998 .+$ Organic + agriculture + and + sustainable+rural+ $\underline{\text { livelihoods }+ \text { in }+ \text { developing }+\mathrm{c} \text { ountries.+ }}$
Report + by + Natural + Resources + and + Ethical+Trade+Programme $\% 2 \mathrm{C}+\mathrm{J}$ une. $\& b \operatorname{bth}=\& \mathrm{hl}=$ en $\&$ as $\mathrm{sdt}=0 \% 2 \mathrm{C} 5$. Accessed on 04.01.2016

Danielou, M. and Ravry, C., 2005. The rise of Ghana's pineapple industry. Africa Region. http://www-wds.worldbank.org/external/ default/WDSContentServer/WDSP/IB/2006/ 01/31/000090341 20060131085841/Rendered/ PDF/349970PAPER0GH0Pineapple 0AFRwp93.pdf. Accessed on 04.01.2016

Daugbjerg, C., Tranter, R., Hattam, C. and Holloway, G. 2011. Modelling the impacts of policy on entry into organic farming: Evidence from Danish-UK comparisons, 1989-2007. Land Use Policy 28(2): 413-422.

Electricity Regulation Authority (ERA), 2015. Statistics and tariffs. Commercial Tariffs. http:/ /www.era.or.ug/index.php/statistics-tariffs/ tariffs/distribution-tariffs/commercial-tariff? $\underline{\text { resetfilters }=0 \& \text { clearordering }=0 \text { \&clearfilters }=0 \text {. }}$. Accessed on 08.01.2016

European Commission. 2005. The new SME definition. User guide and model declaration. https : / / w w w.research.net/r/ EuropeanCommission-FundingTenders-

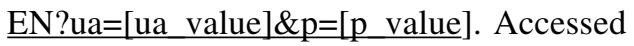
on 28.09.2015.

Food and Agriculture Organisation of the United Nations, FAO. 2010. Characterisation of small farmers in Asia and the Pacific. Siem Reap: FAO. Retrieved from <http://www.fao.org/ fileadmin/templates/ess/documents/ meetings_and_workshops/APCAS23/ documents_OCT10/APCAS-10-28_Small_farmers.pdf>. Accessed 22.10.2015.

Gailhard, Ý.U. and Bojnec, Š. 2015. Farm size and participation in agri-environmental measures: Farm-level evidence from Slovenia. Land Use Policy 46: 273-282.

Gibbon, P. and Bolwig, S. 2007. The economic impact of a ban on imports of air freighted organic products to the UK (No. 2007: 23). DIIS Working Paper.

Gibbon, P. 2006. An overview of the certified organic export sector in Uganda. DIIS Working paper 2006:13.http://www.diis.dk/en/research/ graphics/Publications/WP2006/WP\%20200613.final.til.web.pdf. Accessed on 22.10.2015 
Grunert, K. G., Fruensgaard, J.L., Risom, J, K., Sonne, A. M., Hansen, K., Trondsen, T. and Young, J. A. 2005. Market orientation of value chains: A conceptual framework based on four case studies from the food industry. European Journal of Marketing 39(5/6): 428-455.

Källander, I. and Rundgren, G., 2008. Building sustainable organic sectors. Bonn: IFOAM. http://www.ifoam.bio/sites/default/files/page/ files/building sustainable organic sectors web 1.pdf. Accessed on 4.01.2015

Kaplinsky, R. and Morris, M. 2001. A handbook for value chain research. Working paper prepared for the IDRC. Institute for Development Studies, Brighton, UK.

Kilcher, L., Willer, H., Huber, B., Frieden, C., Schmutz, R. and Schmid, O. 2011. The organic market in Europe. Overview and market access information for producers and international trading companies. Fourteen country examples in the European free trade association and the European Union, with a special focus on Switzerland. FiBL and Sippo, Frick and Zürich. http://orgprints.org/18347/. Accessed on 22.09.2015

Kleemann, L. 2011. Organic pineapple farming in Ghana: A good choice for smallholders? (No. 1671). Kiel Working Papers.

Lazzarini, S. G., Claro, D. P. and Mesquita, L. F. 2008. Buyer-supplier and supplier-supplier alliances: do they reinforce or undermine one another? Journal of Management Studies 45(3):561-584.

Lenné, J.M., Pink, D.A.C., Spence, N.J., Ward, A.F., Njuki, J. and Ota, M. 2005. The vegetable export system: A role model for local vegetable production in Kenya. Outlook on AGRICULTURE 34(4): 225-232.

Lyons, K. and Burch, D. 2008. Socio-economic effects of organic agriculture in Africa. Cultivating the Future Based on Science: 2nd Conference of the International Society of Organic Agriculture Research ISOFAR, Modena, Italy, June 18-20, 2008. http:// orgprints.org/12071/. Accessed on 22.09.2015.

Malins, A. and Nelson, V. 2015. Ethical trade and sustainable rural livelihoods-case studies https://scholar.google.com/scholar? $\mathrm{q}=\mathrm{EPOPA}+$ commercial+loans \&btnG $=\& \mathrm{hl}=$ en\&as sdt=0\%2C5. Accessed on 06.01.2015
Markandya, A., Setboonsarng, S., YuHui, Q., Songkranok, R. and Stefan, A. 2015. The costs of achieving the millennium development goals by adopting organic agriculture 1 . Organic Agriculture and 49.

Mawejje, J., Munyambonera, E. and Bategeka, L. 2012. Uganda Electricity Sector Reforms and Institutional Restructuring. Economic Policy Research Centre Research Series (89).

McDermott, G. A. 2007. The politics of institutional renovation and economic upgrading: Recombining the vines that bind in Argentina. Politics and Society 35(1): 103-144.

Murphy, J.T. 2007. The challenge of upgrading in African industries: Socio-spatial factors and the urban environment in Mwanza, Tanzania. World Development 35(10): 1754-1778.

Nampewo, D. 2012. What Drives Interest Rate Spreads in Uganda's Banking Sector?. Available at SSRN 2141061.

Namuwoza, C. and Tushemerirwe, H. 2011. Uganda: Country Report. The World of Organic Agriculture.http://www.organicworld.net/fileadmin/documents/yearbook/ $2011 /$ namuwoza-tushmerirwe-2011uganda.pdf. Accessed on 28.09.2015.

Nandi, R., Bokelmanna, W., Nithya, V. G. and Dias, G. 2015. Smallholder organic farmer's attitudes, objectives and barriers towards production of organic fruits and vegetables in India: A multivariate analysis. Emirates Journal of Food \& Agriculture 27(5).

NOGAMU. 2012. National Organic Movement of Uganda. Certified Organic Companies in Uganda. http://www.nogamu.org/cope members.php. Accessed on 28.09.2015.

NOGAMU. 2010. National Organic Movement of Uganda. Organic pineapple production. Manual for Organic Pineapple Farmer Trainers. Series No.5.

Padel, S. 2001. Conversion to organic farming: A typical example of the diffusion of an innovation? SociologiaRuralis 41: 40-61. http://dx.doi.org/10.1111/1467-9523.00169. Accessed on 22.09.2015

Pay, E. 2009. The market for organic and fair trade mangoes and pineapples. Study prepared in the framework of FAO project GCP/RAF/404/ GER Increasing incomes and food security of small farmers in West and Central Africa 
through exports of organic and fair trade tropical products. Food and Agriculture Organization of the United Nations (FAO), Trade and Markets Division, Rome, Italy.

Ponte, S. 2002. The latte revolution? Regulation, markets and consumption in the global coffee chain. World Development 30(7):1099-1122.

Perez-Aleman, P. and Sandilands, M. 2008. Building value at the top and bottom of the global supply chain: MNC-NGO partnerships and sustainability. California Management Review 51(1): 24-49.

Peterman, A., Quisumbing, A., Behrman, J. and Nkonya, E. 2011. Understanding the complexities surrounding gender differences in agricultural productivity in Nigeria and Uganda. Journal of Development Studies 47(10): 1482-1509.

Reinikka, R. and Svensson, J. 1999. How inadequate provision of public infrastructure and services affects private investment (No. 2262). World Bank, Development Research Group, Public Economics, and Macroeconomics and Growth.

Setboonsarng, S. 2008. Can ethical trade certification contribute to the attainment of the millennium development goals? A review of organic and fair-trade certification (No. 115). Asian Development Bank Institute Discussion Papers.

Simmons, P., Winters, P. and Patrick, I. 2005. An analysis of contract farming in East Java, Bali, and Lombok, Indonesia. Agricultural Economics 33(s3):513-525.

Stolze, M. and Lampkin, N. 2009. Policy for organic farming: Rationale and concepts. Food Policy 34(3): 237-244.

The World Bank 2015. Lending interest rate (\%). http://data.worldbank.org/indicator/ FR.INR.LEND/countries. Accessed on 29th December 2015.
Trienekens, J.H. 2011. Agricultural value chains in developing countries. A framework for analysis. International Food and Agribusiness Management Review 14(2).

Tumushabe, G., Ruhweza, A., Masiga, M. and Naturinda, B. 2007. Integrated assessment of Uganda's agriculture Sub-Sector: Final Report for UNEP.

Ullah, A., Shah, S.N.M., Ali, A., Naz, R., Mahar, A. and Kalhoro, S.A. 2015. Factors affecting the adoption of organic farming in PeshawarPakistan. Agricultural Sciences 6(06): 587.

van Elzakker, B. and Eyhorn, F. 2010. The organic business guide. Developing sustainable value chains with smallholders. IFOAM and Collaborating Organizations (Helvetas, Agro Eco Louis Bolk Institute, ICCO, UNEP).

Vanslembrouck, I., Van Huylenbroeck, G. and Verbeke, W. 2002. Determinants of the willingness of Belgian farmers to participate in agri-environmental measures. Journal of Agricultural Economics 53 (3): 489-511. doi:10.1111/j.1477-9552.2002.tb00034.x.

Walaga, C., Hauser, M., Delve, R. and Nagawa, F. 2005. Promoting organic agriculture in Uganda. LEISA-LEUSDEN 21(4):9.

Willer, H., Lernoud, J. and Schlatter, B. 2014. Current statistics on organic agriculture worldwide: Organic area, producers and market. The World of Organic Agriculture 46(46):34.

Willer, H., Yussefi, M. and Neil, S. eds. 2008. The World of Organic Agriculture: Statistics and Emerging Trends 2008, Earthscan, London, UK. http://www.researchgate.net/ publication/28679748 The World of Organic Agriculture 2005 Statistics and Emerging Trends. Accessed on 22 October 2015. 